\title{
Potential benefits of Lactobacillus plantarum as probiotic and its advantages in human health and industrial applications: A review
}

\author{
${ }^{1,2}$ Amro Abdelazez, ${ }^{3,4}$ Heba Abdelmotaal, ${ }^{1}$ Zong-Tao Zhu, ${ }^{1}$ Jia Fang-Fang, 5,6Rokayya Sami, ${ }^{1}$ Lu-ji Zhang, ${ }^{7}$ Abdel \\ Rahman Al-Tawaha, ${ }^{1}$ Xiang-Chen Meng
}

${ }^{1}$ Key Laboratory of Dairy Science [Ministry of Education], Northeast Agricultural University, Harbin 150030, China.

${ }^{2}$ Department of Dairy Microbiology, Animal Production Research Institute, Agriculture Research Center, Dokki, Giza, 12618, Egypt.

${ }^{3}$ Department of Microbiology, Soil, Water, Environment, and Microbiology Research Institute, Agriculture Research Center, Giza, 12619, Egypt

${ }^{4}$ Department of Microbiology and Biotechnology, College of Life Sciences, Northeast Agricultural University, Harbin 150030, China.

${ }^{5}$ Department of Nutrition and Food Science, Taif University, Taif, Al-huwayah, 888, Kingdom of Saudi Arabia.

${ }^{6}$ Department of Food Science, Northeast Agricultural University, Harbin, Heilongjiang, 150030, China.

${ }^{7}$ Department of Biological Sciences, Al Hussein Bin Talal University, Ma'an, P.O. Box 20, Jordan.

Correspondence Author: Xiang-Chen Meng, Key Laboratory of Dairy Science [Ministry of Education], Northeast Agricultural University, Harbin 150030, China.

Tel: +86-451-55191813; Fax: +86-451-55190340; E-mail: xchmeng@hotmail.com

Received date: 22 December 2017, Accepted date: 22 January 2018, Online date: 5 February 2018

Copyright: (c) 2018 Amro Abdelazez et al. This is an open-access article distributed under the terms of the Creative Commons Attribution License, which permits unrestricted use, distribution, and reproduction in any medium, provided the original author and source are credited.

\begin{abstract}
The pivotal objective of this study was to focus on the importance of one species of lactic acid bacteria "Lactobacillus plantarum" and its influences on human health as well the applications in food industry. Lactobacillus plantarum is Grampositive bacteria usually found in nature, has industrial importance as a vital element of fermenters used in probiotic fermented food products, which are consumed by an increasing around the worldwide. Further, the potential benefits of $L$. plantarum as a probiotic for human health include regulating the immune system, reducing cholesterol levels, keeping intestinal flora in balance, and reducing the risk of tumours. Substantially, L. plantarum produce lactic acid, antibacterial bioactive compounds, and further exopolysaccharide for express the antagonistic potential against intestinal foodborne pathogens activity. In conclusion, we expressed that review article to focus on the most important aspects of Lactobacillus plantarum in human health and fermented probiotic food productions.
\end{abstract}

Key Words: Lactic acid bacteria. Probiotic. Lactobacillus plantarum. Human health, Industrial application

\section{Probiotics:}

\section{INTRODUCTION}

In recent decades, Foods play a vital role in inhibiting diseases and ensuring health. The main challenge for consumers" requirements for safe, healthy, highquality food, and find innovative new dietary focused on preventing chronic diseases and disorders [1]. The consumption of functional foods (beneficial compounds or foods containing microorganisms) has been shown to enhance health benefits by preventing chronic degenerative diseases (obesity, diabetes, cancer, heart disease, [2]. Interestingly nowadays, various organisms considered probiotic have conventionally been used as starter cultures in fermented foods. Moreover, probiotics available include extremely categories of products for instance pharmaceuticals, different kinds of foods including juices, nutrition bars, infant formulas, relishes and condiments, sweeteners, waters, pizza crust, and other products as well gum, lozenges, dietary supplements, toothpaste, and cosmetics [3]. FAO/WHO [4], reported the definition of the probiotic as, characterized live microorganisms as food or feed supplement, which, when ingested in sufficient amounts, have a beneficial effect on the bacterial flora of the host [5]. Health benefits were expanding interest in developing new models of foods have probiotic microorganisms [6]. Therefore, Probiotics reduce the lactose intolerance symptoms; prevent many kinds of bowel disease and enhancing the balance of intestinal microorganisms [7]. Numerous reports have proven that potential property of probiotics for inhibition of cognitive deficits and enhance brain activity via the microbiome-gut-brain axis. Moreover, numbers of studies suggested that $\mathrm{L}$. rhamnosus and $\mathrm{L}$. plantarum have a vital role on cognitive impairment [8] depression and anxiety or tension [9] and abnormal behaviour in autism spectrum disorder [10]. These impacts are essentially ascribed to the direction of inflammatory signals along the microbiome-gut-brain axis and on the host metabolism. In spite of the exact mechanisms are not clear, these discoveries have recognized a potential probiotic therapy for impeded behavioural reactions [11].

\subsection{Genus and species of probiotics:}

Probiotics existing in a healthy gastrointestinal tract contains a number of genus and species of not less than (85\%) farther pathogeneses (15\%).On the other hand, an unhealthy flora has a dominance of pathogeneses and gets the gastrointestinal tract to be "unbalanced". That causes disease or symptoms of illness. Reasons as a regime, lifestyle, age, stress, and medication might cause the gut flora "imbalance" [12]. Scientific assessments suggested the number of bacterial species between 300 [12] and 1000 [13] with many evaluations around 500 [14]. However, this area of research is still not possible to culture most of these bacteria. On the contrary, we think that the actual numbers of bacteria in the digestive tract are likely to be much greater. Whereas, [15] suggested that microflora about 1014 organisms constituting 400 diverse categories of bacteria. This complicated population of microbial may be considered as "an open the door of comprising the ecosystem groups of microbial populations coexisting in equilibrium in a spatiotemporally defined region".

Figure (1) refers to the complexity of the gastrointestinal microflora ecosystem While the understanding of this system and its interaction is still limited [15]. Therefore, we recommended that all of the people have a unique mix of microorganisms that make up their intestinal microbes, particular species of microorganisms are more common and numerous than others. The main important groups in the human gastrointestinal tract are Lactobacillus and Bifidobacterium 
it obviously uses as probiotic microorganisms in food products [16]. There are several diverse species of these probiotic bacteria further a numerous probiotic as well yeast were expressed in the list below [12].

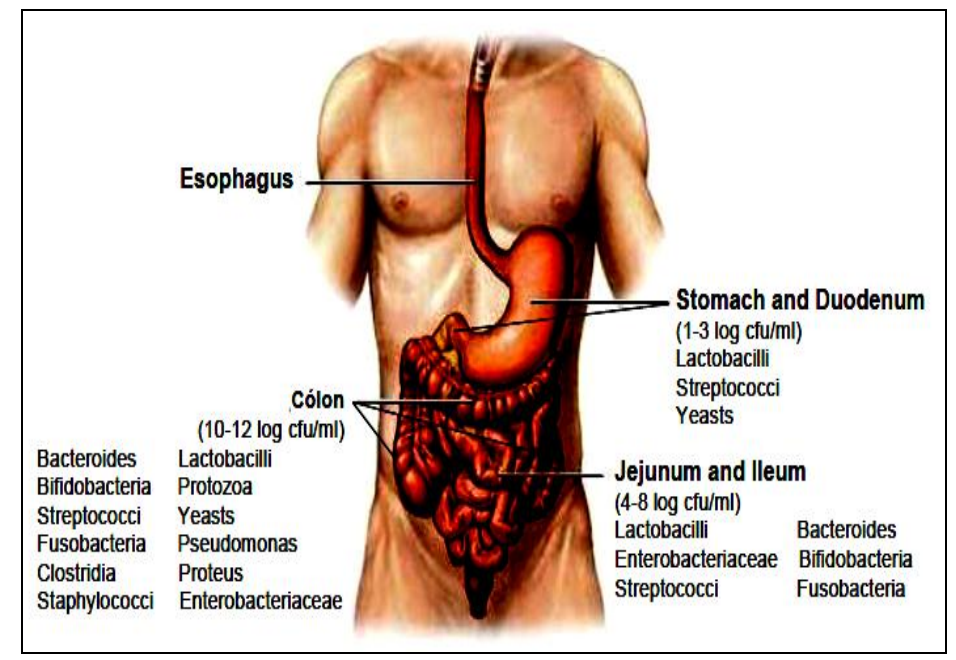

Fig. 1: Microbial colonization of the human gastrointestinal tract (15).

Lactobacilli: Lactobacillus acidophilus; Lactobacillus brevis; Lactobacillus bulgaricus; Lactobacillus casei; Lactobacillus helveticus; Lactobacillus plantarum; Lactobacillus reuteri, and Lactobacillus rhamnosus. Further, Bifidobacteria: Bifidobacterium bifidum; Bifidobacterium infantis; Bifidobacterium lactis; Bifidobacterium longum; Bifidobacterium adolescentis, and Bifidobacterium breve, in addition, Yeast: Saccharomyces boulardii.

\section{Lactic acid bacteria ( $L A B)$ :}

Lactic acid bacteria (LAB) constitute the main group of the Lactobacteriaceae family [17]. They are genetically diverse fermentative organisms with 32-54\% GC content [18]. In addition, lactobacilli demonstrate antifungal [19] anti-tumor activities [20] reduce cholesterol level [21], and antioxidant activity [22]. Furthermore, Lactic acid bacteria (LAB) are one of the most vital probiotic group associated with several functional properties.

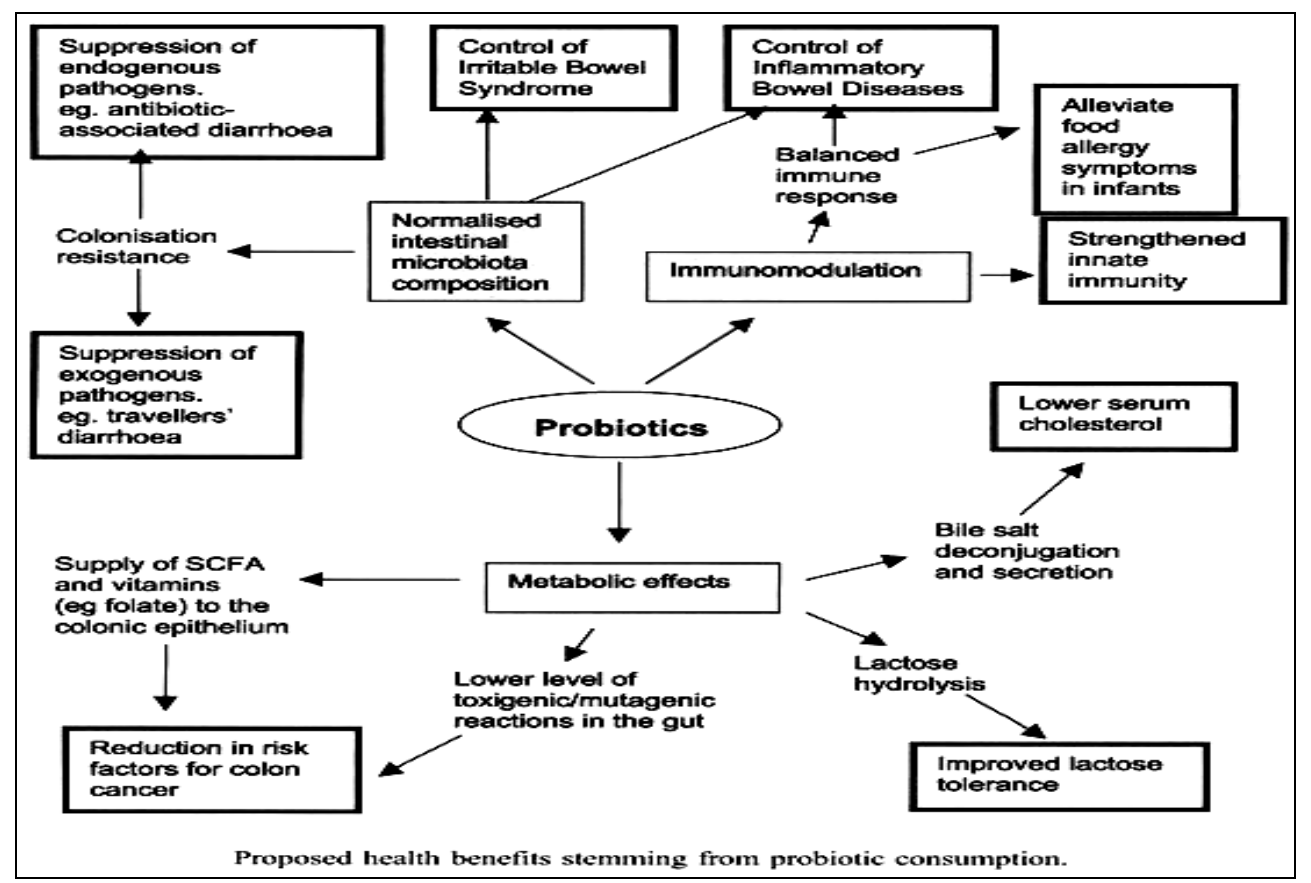

Fig. 2: The diagram for representation of various functions and health benefits of probiotics [23]

Figure (2) illustrate various probiotics advantageous roles of the host [23] such as promoting intestinal advancement, maintaining barrier integrity, regulating the immune system and function of the central nervous system [24]. Synthesis of vitamins, imparting immune-boosting effect, improving lactose absorption etc. [25]. Besides probiotic properties, the starter characteristics of potential probiotics are also critically important, as well fermentability and sensory properties of final products [26]. Probiotics have also been displayed to encourage the treatment of several chronic diseases [27, 28] For instance, diabetes, Alzheimer's, Parkinson's, heftiness, hypertension, liver disorders and urogenital complications and acts as an antioxidant, anti-inflammatory, and anti-obesity agents [29]. Furthermore, it considered as magnificent agents to overproduced compounds of interest, as they own relative simple energy and carbon metabolism and small size of genome compared to other microorganisms as well yeast or fungi [30].

Lactic acid bacteria (LAB) are considered one of the greatest possibilities for assembling for manufacturing "natural food", benign and healthy. These microorganisms are a different group of Gram-positive bacteria, non-sporulation bacteria that produce lactic acid as the most important end product of carbohydrate fermentation. They are a heterogeneous group of bacteria, normally exhibit in naturally rich nutrient environments such as decomposing plants and 
Citation: Amro Abdelazez, Heba Abdelmotaal, Zong-Tao Zhu, Jia Fang-Fang, Rokayya Sami, Lu-ji Zhang, Abdel Rahman Al-Tawaha, Xiang-Chen Meng, 2018. Potential benefits of Lactobacillus plantarum as probiotic and its advantages in human health and industrial applications: A review. Advances in Environmental Biology., 12(1): 16-27.

milk products common among bacteria populating skin and mucosal tissues of humans and animals [31]. In addition, LAB has a low $\mathrm{G}+\mathrm{C}$ content of their genomes and incorporates the accompanying genera: Lactobacillus, Lactococcus, Leuconostoc, Oenococcus, Streptococcus, Pediococcus, Carnobacterium, Enterococcus, Sporolactobacillus, Tetragenococcus, Vagococcus, Weissella and Bifidobacterium [32].

\section{Lactobacillus plantarum:}

Lactobacillus plantarum suggested Streptobacterium plantarum by Orla-Jensen in 1919, is a facultative heterofermentative lactic acid bacterium, which is too great extent dispersed in nature [33]. Lactobacillus plantarum is amazing microbes. Thus, it can adapt to a varied range of different environments. Moreover, because it has the biggest genome ( $\sim 3.3 \mathrm{Mb})$ among the LAB group it can be isolated from varies sources [34]. Furthermore, it extremely tolerance to various harsh conditions including the digestive system stresses [35], gastrointestinal, vaginal, and urogenital tracts [36]. Recently, the focus of using L. plantarum has been increased, particularly in its probiotic potential [37- 39] as well its applications in diverse fermented foods and beverages [40,41] as well fermentation of dairy products likewise cheese, kefir, sauerkraut [42,43], silage [44], wine [45].Moreover, fermented meat products [46], fermented vegetables [47].

\subsection{Physiological, characteristics and growth condition of Lactobacillus plantarum:}

Lactobacillus plantarum generally found in the human and other mammalian gastrointestinal tracts, saliva, and various food products. Furthermore, Furthermore, it is considered one of the most important microbes of positive gram according to the division of lactic acid bacteria (LAB) with short-rod-shaped; also, it is a catalase negative, non-spore forming, facultatively with short-rod-shaped, also it is a catalase negative, non-spore forming, facultatively anaerobic bacterium, micro-aerophilic. Moreover, it acid-tolerant, non-respiring, low $\mathrm{G}+\mathrm{C}$ content, a heterofermentative group of lactobacilli with a range of applications in the food industry as a starter culture and preservatives[48].

In addition, Lactobacillus plantarum grows under the low buffering capacity in the gastrointestinal tract that shows a high tolerance to the consecutive exposure to HCL ( $\mathrm{pH}$ 2.0) and bile salts. Furthermore, it used as cultures in artisanal food fermentation and industrial application. Meanwhile, they contribute to the conservation, flavour, and texture of the fermented foods. Therefore, it can grow at temperatures between $15-450 \mathrm{C}[49,50]$.

As a LAB species, Lactobacillus plantarum requires a fermentable carbohydrate as an energy source, besides it produces lactic acid as the major end-product. The noteworthy adaptation of Lactobacillus plantarum to different ecological niches reflects its capacity to ferment a wide range of carbohydrates, including monosaccharides, disaccharides, and polysaccharides [51]. Table (1) refers to the ability of L. plantarum to grow on a wide variety of sugars [52]. Moreover, it can ferment sugars to produce organic acids, such as acetic acid, succinic acid, and lactic acid, ethanol or carbon dioxide as major metabolites under specific conditions and selective substrates. Whereas depending on the carbon source, these bacteria can switch from using heterofermentative and homofermentative ways of metabolism [53].In addition, Lactobacillus plantarum has developed behaviours to deal with oxidative stress by having catalases, peroxidases, and reductases, as well as a high intracellular concentration of manganese ions $[\mathrm{Mn} 2+]$ to scavenge oxygen radicals also able to obtain and accumulate manganese ions due to the $\mathrm{P}$ type manganese translocation ATPase [54].

Lactobacillus plantarum can possess tannase activity and are able to metabolize phenolic acids. Furthermore, a strain of Lactobacillus plantarum [IFPL935] was capable of metabolizing a flavan-3-ol enriched grape seed extract by means of galloylesterase, decarboxylase, and benzyl alcohol dehydrogenase activities [55].

\subsection{Applications of Lactobacillus plantarum in industry:}

Lactobacillus plantarum is easy to be cultured. Therefore, it highly interested by researchers in the food industry application since it considered a safe probiotic [56].whereas, it can suppress the number of pathogenic microorganisms or maladies that can negatively affect humans or food products. Moreover, Lactobacillus plantarum has widespread applications of the pharma industry by contributing significantly to human medicine without causing any side effects this belongs to the $\mathrm{LAB}$ and has been broadly used as a live diet supplement food industry. In addition, recent research reported that Lactobacillus plantarum could be used as a vaccine vehicle [57]

\subsection{Lactobacillus plantarum as bio-preservative:}

Lactobacillus plantarum is an adaptable and broadly appropriated LAB, it has more notable potential as a probiotic bio-preservative than numerous different Lactobacillus species because of its dual role as an indigenous human gut inhabitant and its long history of safe use as a starter culture in food fermentation. As well, it is one species particularly important as it used in dairy, vegetable and meat fermentations, in the conversion of grass to silage and some strains are marketed as commercial probiotics with health-promoting properties [50].

\section{Antimicrobial and Antagonistic activity against some adverse microorganisms:}

The health claims of L. plantarum permitted to develop different probiotic formulations, and its antibacterial properties are interesting for food safety as in the biopreservation technology (41). Several Lactobacillus plantarum strains have been found to produce different antimicrobial compounds and exhibit antagonistic activity against pathogenic and spoilage bacteria [58-60].

Numerous in vivo reports suggested that the consuming fermented milk containing Lactobacillus plantarum brings activity to the host [61]. In addition, using nine of Lactobacillus plantarum strains identified to suppress the growth of five common foodborne pathogens specifically (Escherichia coli, Staphylococcus aureus, Listeria monocytogenes, Salmonella typhimurium, and Shigella flexneri) that could be presented in fermented milk [39; 62]. Therefore, L. plantarum commonly used with other LAB for the production of some fermented foods with quality products and good organoleptic properties such as texture, taste, chemical content, and flavour nor enhance acidification during the processes of milk fermentation and product storage [63, 64]. In addition, more intermediate antagonistic activity against Helicobacter pylori it has also a strong inhibitory effect in vitro against Streptococcus mutans and Candida albicans, which both are suggested to be associated with caries [65]. Therefore, they can possibly serve additionally as normal probiotic bio-preservatives. However, this continues to be a challenging task due to the stressful environment created by the probiotic bacteria during fermentation and storage.

\subsection{Production of bacteriocins:}

Minutely, lactic acid bacteria (LAB) are well known for their ability to produce pathogen inhibiting substances such as organic acids, hydrogen peroxide, $\mathrm{CO} 2$, diacetyl or antimicrobial peptides, i.e. bacteriocins [66]. In the food industry, bacteriocins "Nisin", produced by Lactococcus lactis subsp lactis, has already been used in more than 50 countries as an antagonistic additive to reduce using the chemical additive such as chemical preservatives. Although nisin has already been applied to food products (e.g. Dairy products) to inhibit pathogen contamination, it is limited to Gram-positive pathogens mainly Listeria monocytogenes (67).

Lactobacillus plantarum strains have several forms of bacteriocins, which isolated from various niches, such as fermented milk, cheese, fermented cucumber, fermented olives, pasta, pineapple, grapefruit juice, sorghum beer and barley, molasses, Boza, kefir, and amasi [68]. Moreover, several reports proved that Lactobacillus plantarum strains have a capability to produce different antimicrobial compounds and exhibit antagonistic activity against pathogenic and spoilage microorganisms [60]. One of the most important groups of these compounds is the bacteriocins, likewise ribosomal synthesized antimicrobial peptides and works against closely related species (69).

Lactobacillus plantarum strains were used for fortifications in the food manufacturing, particularly in the dairy industry. In addition, bacteriocins produced by Lactobacillus plantarum, which called plantaricins, such as PlnA and the two-peptide bacteriocins, PlnJK, PlnEF and plantaricin NC8. Some of these plantaricins have antibacterial activity against both major foodborne pathogens Gram-positive and Gram-negative bacteria, for instance, Salmonella enterica, Escherichia coli, Staphylococcus aureus and Listeria monocytogenes that could contaminate dairy products and cause extreme human diseases [70, 71]such as infective endocarditis, gastroenteritis, maternofetal infections meningoencephalitis etc [72]. 
Citation: Amro Abdelazez, Heba Abdelmotaal, Zong-Tao Zhu, Jia Fang-Fang, Rokayya Sami, Lu-ji Zhang, Abdel Rahman Al-Tawaha, Xiang-Chen Meng, 2018. Potential benefits of Lactobacillus plantarum as probiotic and its advantages in human health and industrial applications: A review. Advances in Environmental Biology., 12(1): 16-27.

Moreover, both PlnEF and PlnJK are two-peptide bacteriocins that belong to the large group of small heat-stable, non-antibiotics termed class II bacteriocins [73]. Plantaricin E, plantaricin F, plantaricin J (Punj) and plantaricin K (PlnK) are cationic peptides that consist of 33, 34, 25, and 32 amino acids having molecular weights of 3703, 3545, 2929, and 3503 Dalton respectively [74]. PlnJ and PlnK are efficient antimicrobials when present together. Notable, no other combinations of these four peptides can improve the antimicrobial activity. The amphiphilic structure of these peptides was assumed to have a role in pore structure. Further, they are usually low molecular weight proteins that reach target cells by binding to cell surface receptors.

\subsection{Antifungal activity:}

Definitely, degradation of cellular DNA, disruption through specific cleavage of 16S rRNA, and inhibition of peptidoglycan synthesis [75, 76]. More than 300 different bacteriocins have been described for the genera Lactobacillus, Lactococcus, Leuconostoc, Pediococcus and Enterococcus [77]. Nowadays, scientists are focused on using a LAB that prevents fungal contamination and consuming demand dramatically increased desire-preserved products. Therefore, reducing potential negative effects of chemical antifungal [78]. It is well known that some lactic acid bacteria produce metabolites that inhibit the growth of fungi and other species of bacteria [79].

Several antifungal compounds have been reported from LAB includes organic acids such as lactic and acetic acids [80, 81], caproic acid [82], a synergic antifungal metabolite like phenyl lactic acid, 3-hydroxylated fatty acids and cyclic dipeptides [83- 85].

Lactobacillus plantarum as a lactic acid bacterium produces antifungal activities that can replace for potentially harmful preservatives in food products [86]. Therefore, several studies reported the ability to inhibit the growth of Rhodotorula mucilaginosa yeast that spoils dairy products and orange juice was determined by examining Lactobacillus plantarum. Inhibition of R. mucilaginosa by Lactobacillus plantarum was tested commercially, FDA approved preservatives such as sodium benzoate and potassium sorbate.

\subsection{Antiviral effects:}

In the past decade, the interest in the immunomodulatory properties of LAB strains has significantly increased. Hence the wide variety of strain-dependent properties have been reported [87], and several in vitro cellular models have been developed in order to analyze and classify the immunomodulatory properties of these strains. Viruses are the most important cause of severe mucosal infections worldwide especially in high-risk populations such as in infants, young children, elderly and immunocompromised hosts. The ability of Lactobacillus plantarum $299 \mathrm{v}$ in preventing rotavirus infection was assessed by plaque assays and genomic analysis. Plaque assays showed that priming with Lactobacillus plantarum $299 \mathrm{v}$ decreased the concentration of live viruses at least by 100 -fold. The gene expression recommended that homeostasis in the gut are maintained in probiotic-primed cells despite infection with rotavirus [88].

The advances in medicine common respiratory virus infections (RVI) such as the common cold or flu continue to cause a considerable economic burden; fortunately, some probiotic strains have been studied for their positive effects on these virus infections [89]. Indeed, products containing probiotics have been shown to have an immunomodulatory effect and a protective effect against RVI in both mice and humans [90]. Daily oral administration of heat-killed Lactobacillus plantarum L-137 (a strain selected for its proinflammatory properties in vitro) enhances protection against influenza virus H1N1 infection by stimulation of type I interferon production challenge in mice enhanced survival and decreased virus titers in lungs of infected mice [91].

Children congenitally exposed to the human immune-deficiency virus [HIV] have received Lactobacillus plantarum 299v in a fermented oatmeal formula [freeze-dried], in pilot-study. The results suggested that Lactobacillus plantarum 299v stimulates specific systemic immune responses after oral supplementation [92].

5. Production of exopolysaccharide (EPS):

The EPS are microbial polysaccharides secreted extracellularly; the amount and their structures depend on the individual microbes and the available carbon substrate [93].

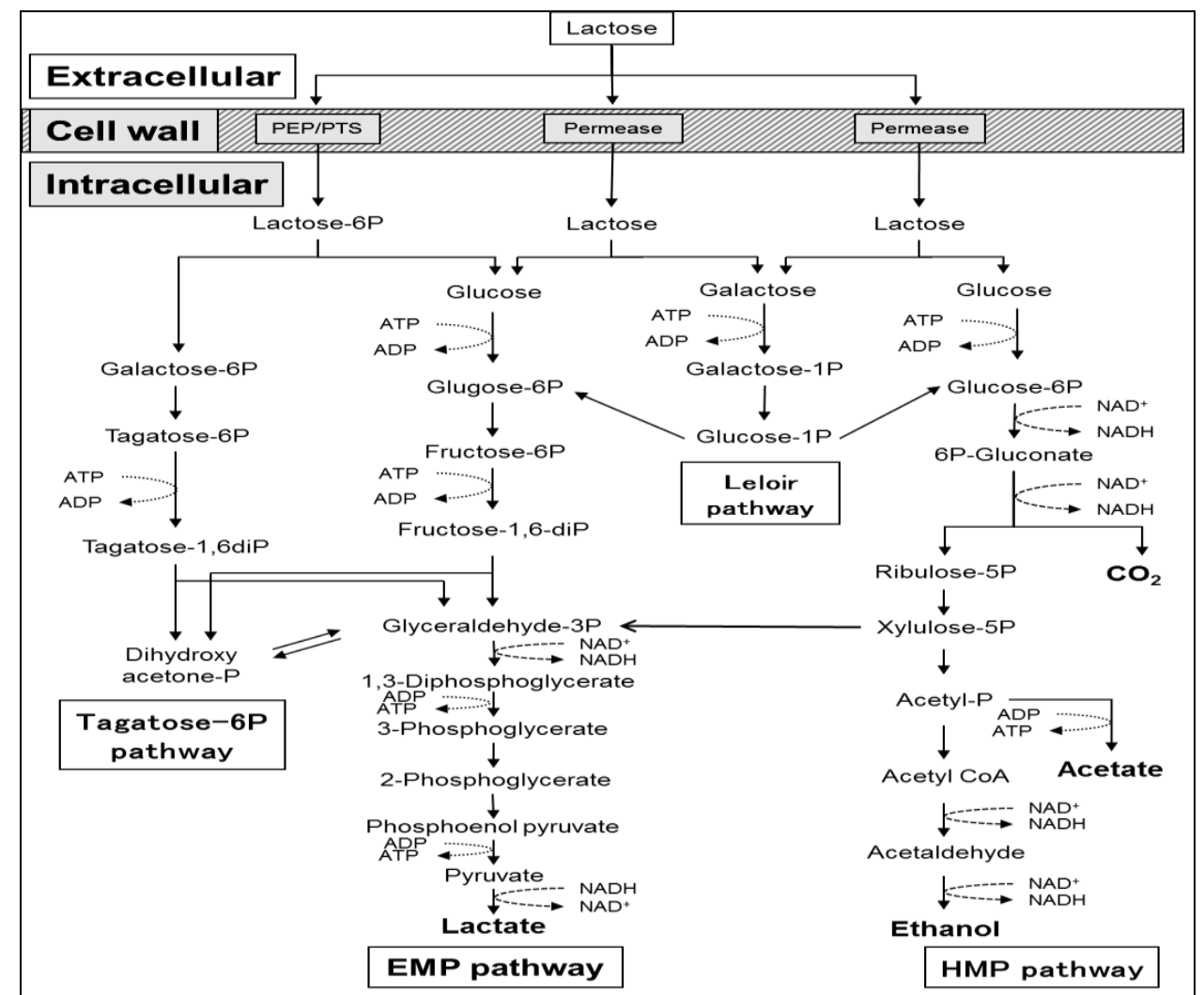

Fig. 3. Exopolysaccharide pathway of lactic acid bacteria [94]. 
Figure (3) explain Exopolysaccharide of lactic acid bacteria pathway [94]. In addition, EPS types namely homopolysaccharides and heteropolysaccharides are secreted by the LAB are long-chain polysaccharide consisting of glucose, galactose, fructose, mannose or other monosaccharides. EPS from LAB can be functional to improve the texture, rheology, and taste of fermented dairy products such as yoghurt and cheese [95].

Recently, some researchers have described LAB exopolysaccharides for their anti-biofilm, antioxidant, antitumor, and immunostimulatory activities [96].Therefore, one of the greatest important bioactive compounds produced by Lactobacillus plantarum is exopolysaccharide (EPS). Various strains of Lactobacillus plantarum can produce hetero-polysaccharides after growing in glucose or lactose [97, 98] or homopolysaccharides, Galatians when lactose is the one of a kind sugar source [99] or glucans when sucrose is the sugar source [100].

Lactobacillus plantarum is a resourceful bacterium of LAB group. Therefore, it has been presented with potential temperance to use as a fruitful probiotic to develop a functional meat product with superior qualities. As well, its capacity with the ability to produce antimicrobial and exopolysaccharides productivity to withstand in harsh conditions as acid, bile and another sensory attribute of the final product with antioxidant potential as the most important idiosyncrasy [101; 85].

Lactobacillus plantarum EPS can interact dynamically over prolonged periods with intestinal mucosa, which presents the greatest surface of interchange between the human body and the external environment. The mucous intestinal microflora, mucosal barrier, and the mucosal immune system can protect the host from detrimental compounds it ingests, such as pathogens [102]. A few reviews were proved that organization of probiotic-fermented milk for a long time could increase dendritic cell numbers in the intestinal mucosal immune system [103].

\section{The health benefit of Lactobacillus plantarum:}

The potential benefits of L. plantarum as a probiotic for human health include regulating the immune system, reducing cholesterol level, stable balance of intestinal microorganisms, and reducing the hazard of tumours [50].

Lactobacillus plantarum cannot expressed the ability as a probiotic to improve the health benefits as long as it cannot aide culture to overcome the physical and chemical barriers such as acid and bile stress in the gastrointestinal tract and keep up a high viability (no less than $106 \mathrm{CFU} / \mathrm{g}$ ) during the quantified product shelf life [16]. The most frequently used probiotic microorganisms are LAB; specifically, lactobacilli and bifidobacteria are considered to have the most amazing potential. Among the lactobacilli, Lactobacillus plantarum is a flexible and commonly distributed species. Its dual role as a native human gut occupant and a protected starter culture in food fermentation, that has stable on it an ideal decision to be utilized as a part of novel food fermentation[50].

\subsection{The benefits of Lactobacillus plantarum and Immunomodulatory properties as a recombinant vaccine:}

In the late 1970s, Lactobacillus plantarum was described as a potential immunological adjuvant [104]. Currently, many studies support the view that L. plantarum enhances the mucosal immune response without negatively influencing immune homeostasis [105]. These traits increase the attractiveness of $\mathrm{L}$. plantarum as a candidate vehicle for antigen delivery.

Recombinant strains of the LAB are used to produce therapeutic proteins and to deliver these proteins to safe mucosal sites. These mucosal surfaces are a major site of pathogen entry. Both systemic and mucosal immune responses can be induced at these surfaces [106]. In addition, they can use to secrete other proteins such as interleukins and antibodies. Moreover, mucosal vaccines can cause IgA secretion and a systemic immune response with T-cells to stimulate the immune system [107].For instance, Lactobacillus plantarum expressing allergens provide a worthwhile technique for immunotherapy compared to subcutaneous and sublingual therapies [108], that beneficial because the allergen will be protected from proteases since it is contained within the bacteria and is cost-effective since the antigen does not have to be processed. Moreover, the components of the allergen and the LAB are presented at the same time as the immune response. Reported have shown that specific strains of Lactobacillus plantarum can be used as delivery vehicles with an allergen to avoid certain allergies, such as dust mite allergies [109]. If a recombinant strain has the dust mite allergen for antigen delivery, it can reduce or prevent the stimulation of the ERK-pathway, which would lead to the suppression of the chemokines that would cause inflammation. In addition, pro-inflammatory recombinant strains of Lactobacillus plantarum are hypothesized to be effective mucosal delivery vehicles for vaccine antigens [106].

The recent study used a strain of Lactobacillus plantarum that expressed invasin from Yersinia pseudotuberculosis. Invasion is a virulence influence that binds to $\beta 1$-integrins on the surface of microfold cells and encourages the uptake of Y. pseudotuberculosis in the intestines. It can also cause inflammation of the host cell by activating the innate immune system by modifying Lactobacillus plantarum so that the extracellular domain of invasin is anchored to the bacterial surface by N-terminal anchoring motifs, this strain of the bacterium can imitate the early infection symptoms of Y. pseudotuberculosis, leading to increasing adjuvant characteristics. In other words, this strain of Lactobacillus plantarum can, using different $\mathrm{N}$-terminal anchoring motifs, target $\mathrm{Y}$. pseudotuberculosis invasin of the cell surface of the bacterium. Since this strain of Lactobacillus plantarum can change the immunological tolerance of an immune response, it can be used to increase antigen immunogenicity and as a delivery vehicle for mucosal vaccines [106].

\subsection{Lactobacillus plantarum enhancing the immunity of human health:}

The intestine is not only an essential place for digestion and absorption but also one of the biggest immune organs of organisms [110]. The gut mucosal immune system is exposed to a wide variety of antigens derived from foods, occupied bacteria, and attacking microorganisms. These need to be limited by a barrier that allows the absorption of nutrients. furthermore, provides immune defence from harmful antigens [111]. However, it remains unknown whether dietary Lactobacillus plantarum in different treatments have any positive effects on the growth performance, the anti-stress proficiency of L. vannamei under normal conditions, and especially under the stress of low salinity.

Lactobacillus plantarum strains have been used for lactic acid fermentation to enhance nutrition, flavour and shelf life, and to reduce levels of toxic heavy metals $(112 ; 113)$. Thus far, no studies have evaluated the effects of LAB strains of Al-induced neuronal injury. One of the recent studies demonstrated that Lactobacillus plantarum CCFM639, a selected candidate probiotic strain with enhanced Al-binding, antioxidative and immunomodulatory abilities in vitro and in vivo, provides significant protection against $\mathrm{Al}$ - toxicity in mice $(114,15)$.

The previous studies as shown in the table (2) have demonstrated that Lactobacillus plantarum could improve immunity [116], disease resistance and survival [117]. Moreover, it demonstrated that probiotics have beneficial effects on human health. Lactobacillus plantarum as an important member of a Probiotic group that can improve the balance of beneficial intestinal microflora in the host organism [118]. Furthermore, Lactobacillus plantarum, specifically, displays various beneficial effects as an anti-cancer agent, an anticoagulant, an antiviral, immune modulator, an anti-inflammatory, an anti-diabetic agent, and an antioxidant; it also exhibits free radical scavenging activity [119]. Moreover, following consumption including maintenance of the colonic microbial balance elimination of potential food toxicants, protection from intestinal infections, and lowering of blood cholesterol [120]. In addition, clinical studies have shown the efficacy of Lactobacillus plantarum strains in the treatment or prevention of gastrointestinal disorders, including irritable bowel syndrome and ulcerative colitis, along with diarrheal diseases, such as antibiotic-associated diarrhoea and Clostridium difficile associated diarrhoea [121]. Moreover, as shown in the table (3), the effects of Lactobacillus plantarum on decreased of total cholesterol in vivo and in vitro experiments.

Lactobacillus plantarum strains can be used to stimulate the production of antibodies. A study using Lactobacillus plantarum that expressed Borrelia burgdorferi OspA lipoprotein found that it stimulated the production of OspA- particular IgA and IgG antibodies as wells as pro- and anti-inflammatory cytokines. It did not lead to secretion of cytokine (IL-8) by epithelial cells and did not induce inflammatory effects. The recombinant Lactobacillus plantarum is fit for empowering a protective immune response via T-cell (Th1/Th2) mediated immunity [107].

\subsection{Anti-allergic activity:}

Some Lactobacillus plantarum strains shown inhibit type I allergic diseases by regulating the immune system [122]. These investigations have revealed that specific probiotic bacteria may be a promising tool for promoting potentially anti-allergic processes through immune regulation. Indeed, the most common antiallergic activity of Lactobacillus plantarum were glycoproteins isolated from some Lactobacillus strains have been known to have beneficial effects, such as 
Citation: Amro Abdelazez, Heba Abdelmotaal, Zong-Tao Zhu, Jia Fang-Fang, Rokayya Sami, Lu-ji Zhang, Abdel Rahman Al-Tawaha, Xiang-Chen Meng, 2018. Potential benefits of Lactobacillus plantarum as probiotic and its advantages in human health and industrial applications: A review. Advances in Environmental Biology., 12(1): 16-27.

controlling immature dendritic cells, regulating $\mathrm{T}$ cell function, and inhibiting the adherence of pathogens in the gut [123]. The glycoprotein [18 kDa] isolated from Lactobacillus plantarum L67 is known to have anti-inflammatory and anti-allergy effects [124].

\section{Application of Lactobacillus plantarum in food production:}

Dairy products are a standout amongst the common carrier for probiotics because milk has all the growth factors required for probiotics [125]. Further, dairy products are frequently supplementary with Probiotics, for instance, cheese, yoghurt and frozen yoghurt [126, 127]. Not surprisingly, several species of this genus, such as L. brevis, L. acidophilus, L. delbrueckii, L. johnsonii, L. salivarius, L. rhamnosus, L. casei, L. paracasei, L. fermentum, L. plantarum, and L. helveticus, are used as starters or non-starters to help in the fermentation and preservation of food [128], as well the production of aroma compounds and bacteriocins which extend their role to biotechnological applications [129]. Lactobacillus plantarum is commonly used in dairy, meat, and plant fermentations also is found in fermented food products such as yoghurt, cheese, kimchi, sauerkraut, sourdough, and pickles [6;130]. The bacterium gives food certain tastes and flavours depending on the balance between acetate (volatile) and lactate (nonvolatile) organic acids [57].Using oxygen and aerating food, producers can control the amount of acetic acid that is produced as the final product of fermentation. An example of this is sourdough fermentation. The bacterium is mainly used for dough acidification, but it can assume a role in the fermentation process.

A particular example of a food item that is produced by Lactobacillus plantarum fermentation is sauerkraut that is spontaneously produced from cabbage through a LAB that is acid tolerant homolactic fermenters. Nonetheless, the essence of sauerkraut varies depending on the type of bacteria used, substrate for fermentation, salt concentration, and temperature of the fermentation. Due to the variation, a study set out to find starter cultures that could be universally used to produce sauerkraut. Leuconostoc mesenteroides was used for the first phase of fermentation and Lactobacillus plantarum for the second. L. mesenteroides provides a mild, pleasant aromatic flavour to the sauerkraut while Lactobacillus plantarum provides it with an acidic, vinegar taste. The researchers observed that by using both bacteria the fermentation time was shortened compared to other fermentation processes [131]. In addition, Lactobacillus plantarum being overwhelming in the acidic, second stage of the fermentation resulted in the inhibition growth of other microorganisms. These two starter bacteria improved the final product of sauerkraut by reducing the fermentation time and the growth of pathogenic microbes.

\section{ACKNOWLEDGMENTS}

The authors are grateful China Scholarship Council [CSC] through a senior scholarship awarded to Amro Abdelazez.

\section{CONCLUSION}

Our study demonstrates Lactobacillus plantarum is a bacterium that is extremely versatile and can adapt to various environmental conditions since it can ferment different types of carbohydrates and sugars. In particular, it can withstand and grow in harsh conditions of the gastrointestinal tract. Therefore, it extremely used as probiotic for human health. A diversity of strains or recombinants of Lactobacillus plantarum can assist in reestablishing the homeostasis of the luxuriance of the flora in the intestines, restrain various pathogenic microorganisms, and could be conceivably utilized as vehicles for vaccines. Within the next few years, it is expected that more developments will be made to utilize the probiotic properties of Lactobacillus plantarum to benefit human health.

Conflict Of Interests:

The authors declare that there is no conflict of interests regarding the publication of this study.

Table 1: the ability of L. plantarum to grow on a wide variety of sugars (Hedberg, M., et al., 2008)

\begin{tabular}{|c|c|c|c|c|c|}
\hline Sugar & Growth & Sugar & Growth & Sugar & Growth \\
\hline Control & - & Inositol & - & Melezitose & + \\
\hline Glycerol & $(+)$ & Mannitol & + & D-raffinose & $(+)$ \\
\hline Erythritol & - & Sorbitol & + & Starch & - \\
\hline D-arabinose & - & $\alpha$ - methyl-D- mannoside & + & Glycogen & - \\
\hline L-arabinose & + & $\alpha$ - methyl-D-glycoside & - & Xylitol & - \\
\hline Ribose & + & $\mathrm{N}$-acetylglucosamine & + & $\beta$-gentiobiose & + \\
\hline D-xylose & - & Amygdalin & + & D-turanose & + \\
\hline L-xylose & - & Arbutin & + & D-lyxose & - \\
\hline Adonitol & - & Esculin & + & D-tagatose & - \\
\hline$\beta$-methylxylidose & - & Salicin & + & D-fucose & - \\
\hline Galactose & + & Cellobiose & + & L- fucose & - \\
\hline D-glucose & + & Maltose & + & D-arabitol & $(+)$ \\
\hline D-fructose & + & Lactose & + & L-arabitol & - \\
\hline D-mannose & + & Melibiose & + & Gluconate & + \\
\hline L-sorbose & - & Sucrose & + & 2-ketogluconate & - \\
\hline Rhamnose & $(+)$ & Trehalose & + & 5-ketogluconate & - \\
\hline Dulcitol & - & Inulin & - & & \\
\hline
\end{tabular}

Table 2: Uses of Lactobacillus plantarum strains to improve the health benefits and of natural immune response.

\begin{tabular}{|c|c|c|c|c|c|}
\hline $\begin{array}{l}\text { Lactobacillus } \\
\text { plantarum strains }\end{array}$ & Action & Dose / Sources & Intake & Host & References \\
\hline L. plantarum $299 \mathrm{v}$ & Increased short-chain fatty acid content of faeces & $2.0 \times 10^{10}$ & 3 weeks & Human & $\begin{array}{l}\text { (Johansson, } \\
\text { M.L., et al., } \\
\text { 1998) }\end{array}$ \\
\hline $\begin{array}{l}\text { L. plantarum } 299 \mathrm{v} \\
\text { and L. plantarum } 299\end{array}$ & $\begin{array}{l}\text { Changing microbiota in ileum and rectum Dominant } \\
\text { recovery of } L \text {. plantarum ( } 2 / 3 \text { of recovered strains) }\end{array}$ & $5.0 \times 10^{8}$ & 10 days & Human & $\begin{array}{l}\text { (Johansson, } \\
\text { M.L., et al., } \\
\text { 1993) }\end{array}$ \\
\hline L. plantarum $299 \mathrm{v}$ & No effect on post-operative wound infection & $2.5 \times 10^{10}$ & Differed & Human & $\begin{array}{l}\text { (McNaught } \\
\text {, C.E., et } \\
\text { al., 2002) }\end{array}$ \\
\hline L. plantarum $299 \mathrm{v}$ & $\begin{array}{l}\text { Up to six times reduction in carriage of faecal } \\
\text { Enterobacteriaceae }\end{array}$ & Unknown & 13 days & Human & $\begin{array}{l}\text { (Kingamko } \\
\text { no, R., et } \\
\text { al., 1999) }\end{array}$ \\
\hline L. plantarum $299 \mathrm{v}$ & Improved natural immune response & Unknown & 4 weeks & Children exposed to HIV & $\begin{array}{l}\text { (Cunningha } \\
\text { m-Rundles, }\end{array}$ \\
\hline
\end{tabular}


Citation: Amro Abdelazez, Heba Abdelmotaal, Zong-Tao Zhu, Jia Fang-Fang, Rokayya Sami, Lu-ji Zhang, Abdel Rahman Al-Tawaha, Xiang-Chen Meng, 2018.

Potential benefits of Lactobacillus plantarum as probiotic and its advantages in human health and industrial applications: A review. Advances in Environmental

Biology., 12(1): 16-27.

\begin{tabular}{|c|c|c|c|c|c|}
\hline & & & & & $\begin{array}{l}\text { S., et al., } \\
2000)\end{array}$ \\
\hline L. plantarum $299 \mathrm{v}$ & $\begin{array}{l}1 / 3 \text { reduction in recurrence of Clostridium difficile } \\
\text { associated diarrhoea }\end{array}$ & $5.0 \times 10^{10}$ & 38 days & Human & $\begin{array}{ll}\text { (Wullt, } & \text { M., } \\
\text { et } & \text { al., } \\
2003) & \\
\end{array}$ \\
\hline L. plantarum $299 \mathrm{v}$ & Reduction in symptoms IBS & $2.0 \times 10^{10}$ & 4 weeks & Human & $\begin{array}{l}\text { (Niedzielin, } \\
\text { K., et al., } \\
\text { 2001) }\end{array}$ \\
\hline L. plantarum $299 \mathrm{v}$ & No reduction in symptoms IBS & $6.3 \times 10^{9}$ & 4 weeks & Human & $\begin{array}{l}\text { (Sen, S., et } \\
a l ., 2002)\end{array}$ \\
\hline L. plantarum & $\begin{array}{l}\text { Decrease enterobacteriaceae and clostridia and slight } \\
\text { increase enterococci }\end{array}$ & $1.4 \times 10^{9}$ & 7 days & $\begin{array}{l}\text { SHIME (GI-tract } \\
\text { model) }\end{array}$ & $\begin{array}{l}\text { (Alander, } \\
\text { M., et al., } \\
\text { 1999) }\end{array}$ \\
\hline L. plantarum $299 \mathrm{v}$ & $\begin{array}{l}\text { Increase of IL- } 8 \text { mRNA in epithelial cells and down- } \\
\text { regulation of IL- } 8 \text { secretion }\end{array}$ & $\begin{array}{l}1 \mathrm{cfu} / 1000 \\
\text { cells }\end{array}$ & $3 \mathrm{~h}$ & $\begin{array}{l}\text { Human cell line } \\
\text { HT-29 }\end{array}$ & $\begin{array}{l}\text { (McCracke } \\
\text { n, V.J., et } \\
\text { al., 2002) }\end{array}$ \\
\hline L. plantarum $299 \mathrm{v}$ & Inhibition of EPEC induced neutrophil migration & $\begin{array}{ll}10^{7}, & 10^{8}, \text { and } \\
10^{9} & \end{array}$ & $2.5 \mathrm{~h}$ & T-84 cell line & $\begin{array}{l}\text { (Michail, S } \\
\text { and F. } \\
\text { Abernathy, } \\
\text { 2003) }\end{array}$ \\
\hline L. plantarum $299 \mathrm{v}$ & Inhibition of enteropathogenic E. coli adherence & $\begin{array}{l}10^{5}, \quad 10^{7}, \quad 10^{8} \\
\text { and } 10^{9}\end{array}$ & & $\begin{array}{l}\text { Human cell line } \\
\text { HT-29 }\end{array}$ & $\begin{array}{l}\text { (Mack, } \\
\text { D.R., et al., } \\
\text { 1999) }\end{array}$ \\
\hline $\begin{array}{l}\text { L. plantarum CRL } \\
936\end{array}$ & Increase in specific and unspecific immunity & $10^{9}$ & $\begin{array}{l}2,5 \text { or } 7 \\
\text { days }\end{array}$ & Mice & $\begin{array}{l}\text { (Perdigon, } \\
\text { G., et al., } \\
\text { 1999) }\end{array}$ \\
\hline L. plantarum $299 \mathrm{v}$ & Inhibition of $E$. coli induced intestinal permeability & $\begin{array}{l}\text { Differed per } \\
\text { group }\end{array}$ & 1 week & Rats & $\begin{array}{l}\text { (Mangell, } \\
\text { P., et al., } \\
\text { 2002) }\end{array}$ \\
\hline L. plantarum $299 \mathrm{v}$ & $\begin{array}{l}\text { Reduction in side effects of external radiation on colon } \\
\text { anastomotic healing }\end{array}$ & 22 days & $2 \times 10^{9}$ & Rats & $\begin{array}{l}\text { (Liu, Q., et } \\
\text { al., 2001) }\end{array}$ \\
\hline $\begin{array}{l}\text { Lactobacillus } \\
\text { plantarum OLL2712 }\end{array}$ & $\begin{array}{l}\text { Significantly decreased the production of } \\
\text { proinflammatory } \\
\text { cytokines in vitro. Significantly suppressed } \\
\text { proinflammatory cytokines levels in both visceral } \\
\text { adipose tissues and the serum of KKAy mice, and } \\
\text { reduced serum triglycerides concentration/ Alleviation } \\
\text { of oxidative stress and adrenaline levels in the serum of } \\
\text { KKAy mice. Of all LAB strains used in this study, this } \\
\text { strain induced the highest levels of IL-10 production in } \\
\text { mouse-derived dendritic cells and peritoneal } \\
\text { macrophages. }\end{array}$ & & & Fermented milk & $\begin{array}{l}\text { (Toshimits } \\
\text { u, T., et al., } \\
\text { 2016) }\end{array}$ \\
\hline $\begin{array}{l}\text { Lactobacillus } \\
\text { plantarum Q180 }\end{array}$ & $\begin{array}{l}\text { Showed a lipase inhibitory activity of } 83.61 \pm 2.32 \% \\
\text { and inhibited adipocyte differentiation of } 3 \mathrm{~T} 3-\mathrm{L} 1 \mathrm{cells} \\
(14.63 \pm 1.37 \%) \text { at a concentration of } 100 \mu \mathrm{g} / \mathrm{mL} \text {. It } \\
\text { also did not produce carcinogenic enzymes such as } \beta \text { - } \\
\text { glucuronidase. }\end{array}$ & & & $\begin{array}{l}\text { Fecal samples of healthy } \\
\text { adults }\end{array}$ & $\begin{array}{l}\text { (Park, S.Y., } \\
\text { et al., } \\
2014)\end{array}$ \\
\hline $\begin{array}{l}\text { Lactobacillus } \\
\text { plantarum }\end{array}$ & $\begin{array}{l}\text { Positive correlation with endotoxin levels and lowering } \\
\text { of body weight in studied patients. }\end{array}$ & & & & $\begin{array}{lr}\text { (Lee, } & \text { S.J., } \\
\text { et } & \text { al., } \\
2014) & \\
\end{array}$ \\
\hline $\begin{array}{l}\text { Lactobacillus } \\
\text { plantarum NCU116 }\end{array}$ & $\begin{array}{l}\text { Significantly affecting biological pathways and } \\
\text { processes, including metabolism of lipids, lipoproteins, } \\
\text { purine, tryptophan, bile secretion, fatty acid } \\
\text { biosynthesis, glycolysis and gluconeogenesis. }\end{array}$ & & & & $\begin{array}{l}(\mathrm{Li}, \mathrm{C} ., \text { et } \\
\text { al., 2016) }\end{array}$ \\
\hline $\begin{array}{l}\text { Lactobacillus } \\
\text { plantarum FSGB }\end{array}$ & $\begin{array}{l}\text { effect on body weight and blood glucose/serum } \\
\text { parameters when administered at a dose of } 0.5 \mathrm{~g} / \mathrm{kg} \text { in } \\
\text { obese } \mathrm{db} / \mathrm{db} \text { mice. FSGB improved insulin and glucose } \\
\text { tolerance levels. Furthermore, enhanced immune } \\
\text { activities by increasing immune cell population and } \\
\text { glucose transporter } 1 \text { (GLUT1) mRNA expression in } \\
\text { L6 cells was up-regulated, showing that FSGB may } \\
\text { increase glucose activity transport to target cells. }\end{array}$ & & & & $\begin{array}{l}\text { (Kim, } \\
\text { et } \quad \text { S.T., } \\
2012)\end{array}$ \\
\hline
\end{tabular}

Table 3: Effects of Lactobacillus plantarum in the reduction of cholesterol and decrease triglycerides in vivo and in vitro experiments.

\begin{tabular}{|l|l|l|}
\hline Experimental system & Major findings & Reference \\
\hline Mice & Reduced blood cholesterol Decreased triglycerides & $\begin{array}{l}\text { (Nguyen, } \\
\text { T.D., et al., } \\
2007)\end{array}$ \\
\hline Rat and Culture media & Decreased total cholesterol and LDL-cholesterol & $\begin{array}{l}\text { (Kumar, R., et } \\
\text { al., 2001) }\end{array}$ \\
\hline Rat & $\begin{array}{l}\text { Decreased LDL, VLDL, and increased HDL with decrease in deposition of cholesterol and } \\
\text { triglyceride in liver and aorta }\end{array}$ & $\begin{array}{l}\text { Mohania, D., } \\
\text { et al., 2013) }\end{array}$ \\
\hline Culture media & Cholesterol assimilation & (Tomaro- \\
& & $\begin{array}{l}\text { Duchesneau, } \\
\text { C., et al., }\end{array}$ \\
\hline
\end{tabular}


Citation: Amro Abdelazez, Heba Abdelmotaal, Zong-Tao Zhu, Jia Fang-Fang, Rokayya Sami, Lu-ji Zhang, Abdel Rahman Al-Tawaha, Xiang-Chen Meng, 2018. Potential benefits of Lactobacillus plantarum as probiotic and its advantages in human health and industrial applications: A review. Advances in Environmental Biology., 12(1): 16-27.

\begin{tabular}{|c|c|c|}
\hline & & 2014) \\
\hline Human & Reduction in LDL cholesterol (9.6\%) and fibrinogen (13.5\%) & $\begin{array}{l}\text { (Bukowska, } \\
\text { H., et al., } \\
1998)\end{array}$ \\
\hline Human & Reduction in LDL cholesterol (11.7\%) and fibrinogen (21.0\%) & $\begin{array}{l}\text { (Naruszewicz, } \\
\text { M., et al., } \\
2002)\end{array}$ \\
\hline Force of Kimchi samples & $\begin{array}{l}\text { Prevention of weight gain and body fat accumulation in diet-induced obese rats. A significant } \\
\text { decrease in organ weight except in the weight of testis. A significant decrease in total cholesterol, } \\
\text { LDL-cholesterol, and triglycerides. A significant decrease in blood glucose levels, and plasma } \\
\text { levels of insulin, leptin, and ghrelin }\end{array}$ & $\begin{array}{l}\text { (Hong, S.M., } \\
\text { et al., 2015) }\end{array}$ \\
\hline Naturally-fermented Kimchi & $\begin{array}{l}\text { A significant decrease in triglyceride levels and increased levels of intracellular glycerol and lipid } \\
\text { lipolysis. Stimulated reduction in the mRNA levels of PPAR- } \gamma, \text { C/EBP- } \alpha \text {, and FAS, which are } \\
\text { related to adipogenesis/lipogenesis in 3T3-L1 cells. }\end{array}$ & $\begin{array}{l}\text { (Lee, K.H., et } \\
\text { al., 2015) }\end{array}$ \\
\hline $\begin{array}{l}\text { Soy milk fermented products } \\
\text { (SM101 and SM102) }\end{array}$ & $\begin{array}{l}\text { Inhibition of 3T3-L1 differentiation and the accumulation of free fatty acids markedly increased } \\
\text { in rats. Greater up-regulation and down-regulation of lipolysis and heparin-releasable lipoprotein } \\
\text { lipase, respectively, were observed in the 3T3-L1 adipocytes of treated rats. }\end{array}$ & $\begin{array}{l}\text { (Lee, B.H., et } \\
\text { al., 2013) }\end{array}$ \\
\hline
\end{tabular}

\section{REFERENCES}

[1] Salvetti E and O'Toole PW, 2017.When regulation challenges innovation: The case of the genus Lactobacillus. Trends in Food Science \& Technology, 66:187-94.

[2] Abdelazez A, Muhammad Z, Zhang QX, Zhu ZT, Abdelmotaal H, Sami R and Meng XC, 2017. Production of a Functional Frozen Yogurt Fortified with Bifidobacterium spp. BioMed research international, 6438528:1-10.

[3] Hoffmann DE, Fraser CM, Palumbo F and Ravel J, 2014. Probiotics: achieving a better regulatory fit. Food \& Drug LJ, 69:237.

[4] Joint FAO/WHO Expert Committee on Food Additives. Meeting, World Health Organization. Evaluation of certain mycotoxins in food: Fifty-sixth report of the Joint FAO/WHO Expert Committee on Food Additives. World Health Organization; 2002.

[5] Hill C, Guarner F, Reid G, Gibson GR, Merenstein DJ, Pot B, Morelli L, Canani RB, Flint HJ, Salminen S and Calder PC, 2014. Expert consensus document: The International Scientific Association for Probiotics and Prebiotics consensus statement on the scope and appropriate use of the term probiotic. Nature Reviews Gastroenterology and Hepatology, 11(8):506-514.

[6] Sidira M, Santarmaki V, Kiourtzidis M, Argyri AA, Papadopoulou OS, Chorianopoulos N, Tassou C, Kaloutsas S, Galanis A and Kourkoutas Y, 2017. Evaluation of immobilized Lactobacillus plantarum 2035 on whey protein as an adjunct probiotic culture in yoghurt production. LWT-Food Science and Technology, 75:137-146.

[7] Lomer MC, Parkes GC and Sanderson JD, 2008. Lactose intolerance in clinical practice-myths and realities. Alimentary pharmacology \& therapeutics, 27(2):93-103.

[8] Liu YW, Liu WH, Wu CC, Juan YC, Wu YC, Tsai HP, Wang S and Tsai YC, 2016. Psychotropic effects of Lactobacillus plantarum PS128 in early lifestressed and naïve adult mice. Brain research, 1631:1-2.

[9] Bravo JA, Forsythe P, Chew MV, Escaravage E, Savignac HM, Dinan TG, Bienenstock J and Cryan JF, 2011. Ingestion of Lactobacillus strain regulates emotional behavior and central GABA receptor expression in a mouse via the vagus nerve. Proceedings of the National Academy of Sciences, 108(38):16050-16055.

[10] Hsiao EY, McBride SW, Hsien S, Sharon G, Hyde ER, McCue T, Codelli JA, Chow J, Reisman SE, Petrosino JF, Patterson PH, 2013. Microbiota modulate behavioral and physiological abnormalities associated with neurodevelopmental disorders. Cell, 155(7):1451-1463.

[11] Zheng X, Zhang X, Kang A, Ran C, Wang G and Hao H, 2015. Thinking outside the brain for cognitive improvement: Is peripheral immunomodulation on the way? Neuropharmacology, 96:94-104.

[12] Guarner F and Malagelada JR. Gut flora in health and disease 2003. The Lancet, 361(9356):512-519.

[13] Sears CL. A dynamic partnership: celebrating our gut flora 2005. Anaerobe, 11(5):247-251.

[14] Steinhoff U. Who controls the crowd? New findings and old questions about the intestinal microflora 2005. Immunology letters, 99(1):12-6.

[15] Holzapfel WH, Haberer P, Snel J and Schillinger U, 1998. Overview of gut flora and probiotics. International journal of food microbiology, 41(2):85-101.

[16] Tripathi MK and Giri SK, 2014. Probiotic functional foods: Survival of probiotics during processing and storage. Journal of functional foods, 9:225-241.

[17] Canchaya C, Claesson MJ, Fitzgerald GF, Van Sinderen D and O'Toole PW, 2006. Diversity of the genus Lactobacillus revealed by comparative genomics of five species. Microbiology, 152(11):3185-96.

[18] Singh S, Goswami P, Singh R and Heller KJ, 2009. Application of molecular identification tools for Lactobacillus, with a focus on discrimination between closely related species: a review. LWT-Food Science and Technology, 42(2):448-457.

[19] Yang EJ and Chang HC, 2010. Purification of a new antifungal compound produced by Lactobacillus plantarum AF1 isolated from kimchi. International journal of food microbiology, 139(1-2):56-63.

[20] Paolillo R, Carratelli CR, Sorrentino S, Mazzola N and Rizzo A, 2009. Immunomodulatory effects of Lactobacillus plantarum on human colon cancer cells. International immunopharmacology, 9(11):1265-1271.

[21] Wang J, Zhang H, Chen X, Chen Y and Bao Q, 2012. Selection of potential probiotic lactobacilli for cholesterol-lowering properties and their effect on cholesterol metabolism in rats fed a high-lipid diet. Journal of dairy science, 95(4):1645-1654.

[22] Kuda T, Kawahara M, Nemoto M, Takahashi H and Kimura B, 2014. In vitro antioxidant and anti-inflammation properties of lactic acid bacteria isolated from fish intestines and fermented fish from the Sanriku Satoumi region in Japan. Food research international, 64:248-255.

[23] Saarela M, Lähteenmäki L, Crittenden R, Salminen S and Mattila-Sandholm T, 2002. Gut bacteria and health foods-the European perspective. International journal of food microbiology, 78(1-2):99-117.

[24] Braniste V, Al-Asmakh M, Kowal C, Anuar F, Abbaspour A, Tóth M, Korecka A, Bakocevic N, Ng LG, Kundu P and Gulyás B, 2014. The gut microbiota influences blood-brain barrier permeability in mice. Science translational medicine, 6(263):263ra158.

[25] Mansouripour S, Esfandiari Z, Nateghi L, 2013. The effect of heat process on the survival and increased viability of probiotic by microencapsulation: a review. Ann Biol Res, 4(4):83-87.

[26] Mohammadi R, Sohrabvandi S and Mohammad A, 2012. The starter culture characteristics of probiotic microorganisms in fermented milks. Engineering in Life Sciences, 12(4):399-409.

[27] Ji K, Jang NY and Kim YT, 2015. Isolation of lactic acid bacteria showing antioxidative and probiotic activities from kimchi and infant feces. J. Microbiol. Biotechnol, 25(9):1568-1577. 
Citation: Amro Abdelazez, Heba Abdelmotaal, Zong-Tao Zhu, Jia Fang-Fang, Rokayya Sami, Lu-ji Zhang, Abdel Rahman Al-Tawaha, Xiang-Chen Meng, 2018. Potential benefits of Lactobacillus plantarum as probiotic and its advantages in human health and industrial applications: A review. Advances in Environmental Biology., 12(1): 16-27.

[28] Xing J, Wang G, Zhang Q, Liu X, Gu Z, Zhang H, Chen YQ and Chen W, 2015. Determining antioxidant activities of lactobacilli cell-free supernatants by cellular antioxidant assay: a comparison with traditional methods. PloS one, 10(3):e0119058.

[29] Woo JY, Gu W, Kim KA, Jang SE, Han MJ and Kim DH, 2014. Lactobacillus pentosus var. plantarum C29 ameliorates memory impairment and inflammaging in a D-galactose-induced accelerated aging mouse model. Anaerobe, 27:22-26.

[30] Papagianni M, 2012. Recent advances in engineering the central carbon metabolism of industrially important bacteria. Microbial cell factories, 11(1):50(1:13).

[31] Mangiapane E, Mazzoli R, Pessione A, Svensson B, Riedel K and Pessione E, 2015. Ten years of subproteome investigations in lactic acid bacteria: a key for food starter and probiotic typing. Journal of proteomics, 127:332-339.

[32] Douillard FP and De Vos WM, 2014. Functional genomics of lactic acid bacteria: from food to health. In Microbial cell factories. Bio Med Central, 13(1): S8(1-21).

[33] Siezen RJ, Tzeneva VA, Castioni A, Wels M, Phan HT, Rademaker JL, Starrenburg MJ, Kleerebezem M, Molenaar D and Van Hylckama Vlieg JE, 2010. Phenotypic and genomic diversity of Lactobacillus plantarum strains isolated from various environmental niches. Environmental Microbiology, (3):758773.

[34] Martino ME, Bayjanov JR, Caffrey BE, Wels M, Joncour P, Hughes S, Gillet B, Kleerebezem M, van Hijum SA and Leulier F, 2016. Nomadic lifestyle of Lactobacillus plantarum revealed by comparative genomics of 54 strains isolated from different habitats. Environmental microbiology, 18(12):4974-4989.

[35] Parente E, Ciocia F, Ricciardi A, Zotta T, Felis GE, Torriani S, 2010. Diversity of stress tolerance in Lactobacillus plantarum, Lactobacillus pentosus and Lactobacillus paraplantarum: a multivariate screening study. International journal of food microbiology, 144(2):270-9.

[36] Jose NM, Bunt CR and Hussain MA, 2015. Comparison of microbiological and probiotic characteristics of lactobacilli isolates from dairy food products and animal rumen contents. Microorganisms, 3(2):198-212.

[37] Huang R, Tao X, Wan C, Li S, Xu H, Xu F, Shah NP and Wei H, 2015. In vitro probiotic characteristics of Lactobacillus plantarum ZDY 2013 and its modulatory effect on gut microbiota of mice. Journal of dairy science, 98(9):5850-5861.

[38] Khan I and Kang SC, 2016. Probiotic potential of nutritionally improved Lactobacillus plantarum DGK-17 isolated from Kimchi-A traditional Korean fermented food. Food Control, 60:88-94.

[39] Li C, Chen Y, Kwok LY, Chen X, Yu H, Yang H, Yang J, Xue J, Sun T and Zhang H, 2015. Identification of potential probiotic Lactobacillus plantarum isolates with broad-spectrum antibacterial activity. Dairy science \& technology, 95(3):381-92.

[40] Milioni C, Martínez B, Degl'Innocenti S, Turchi B, Fratini F, Cerri D and Fischetti R, 2015. A novel bacteriocin produced by Lactobacillus plantarum LpU4 as a valuable candidate for biopreservation in artisanal raw milk cheese. Dairy science \& technology, 95(4):479-494.

[41] Russo P, Arena MP, Fiocco D, Capozzi V, Drider D and Spano G, 2017. Lactobacillus plantarum with broad antifungal activity: A promising approach to increase safety and shelf-life of cereal-based products. International journal of food microbiology, 247:48-54.

[42] Agaliya PJ and Jeevaratnam K, 2012. Screening of Lactobacillus plantarum isolated from fermented idli batter for probiotic properties. African Journal of Biotechnology, 11(65):12856-12864.

[43] Chang MH, Hong SF, Chen JH, Lin MF, Chen CS and Wang SC, 2016. Antibacterial activity Lactobacillus plantarum isolated from fermented vegetables and investigation of the plantaricin genes. African Journal of Microbiology Research, 10(22):796-803.

[44] Arasu MV, Jung MW, Kim DH, Park HS, Ilavenil S, Al-Dhabi NA and Choi KC, 2015. Identification and phylogenetic characterization of novel Lactobacillus plantarum species and their metabolite profiles in grass silage. Annals of microbiology, 65(1):15-25.

[45] Berbegal C, Peña N, Russo P, Grieco F, Pardo I, Ferrer S, Spano G and Capozzi V, 2016. Technological properties of Lactobacillus plantarum strains isolated from grape must fermentation. Food microbiology, 57:187-194.

[46] Schillinger U and Lücke FK,1989. Antibacterial activity of Lactobacillus sake isolated from meat. Applied and environmental microbiology, 55(8):19011906.

[47] Khemariya P, Singh S, Jaiswal N and Chaurasia SN, 2016. Isolation and identification of Lactobacillus plantarum from vegetable samples. Food Biotechnology, 30(1):49-62.

[48] Holzapfel WH, Haberer P, Geisen R, Björkroth J and Schillinger U, 2001. Taxonomy and important features of probiotic microorganisms in food and nutrition-. The American journal of clinical nutrition, 73(2):365s-73s.

[49] Valan Arasu M, Jung MW, Ilavenil S, Jane M, Kim DH, Lee KD, Park HS, Hur TY, Choi GJ, Lim YC and Al-Dhabi NA, 2013. Isolation and characterization of antifungal compound from Lactobacillus plantarum KCC-10 from forage silage with potential beneficial properties. Journal of applied microbiology, 115(5):1172-85.

[50] De Vries MC, Vaughan EE, Kleerebezem M and de Vos WM, 2006. Lactobacillus plantarum—survival, functional and potential probiotic properties in the human intestinal tract. International Dairy Journal, 16(9):1018-1028.

[51] Bringel F, Quénée P and Tailliez P, 2001. Polyphasic investigation of the diversity within Lactobacillus plantarum related strains revealed two L. plantarum subgroups. Systematic and applied microbiology, 24(4):561-571.

[52] Hedberg M, Hasslöf P, Sjöström I, Twetman S and Stecksén-Blicks C, 2008. Sugar fermentation in probiotic bacteria-an in vitro study. Molecular Oral Microbiology, 23(6):482-485.

[53] Di Cagno R, Minervini G, Sgarbi E, Lazzi C, Bernini V, Neviani E and Gobbetti M, 2010. Comparison of phenotypic (Biolog System) and genotypic (random amplified polymorphic DNA-polymerase chain reaction, RAPD-PCR, and amplified fragment length polymorphism, AFLP) methods for typing Lactobacillus plantarum isolates from raw vegetables and fruits. International journal of food microbiology, 143(3):246-523.

[54] Kleerebezem M, Boekhorst J, van Kranenburg R, Molenaar D, Kuipers OP, Leer R, Tarchini R, Peters SA, Sandbrink HM, Fiers MW and Stiekema W, 2003. Complete genome sequence of Lactobacillus plantarum WCFS1. Proceedings of the National Academy of Sciences, 100(4):1990-1995.

[55] Tabasco R, Sánchez-Patán F, Monagas M, Bartolomé B, Moreno-Arribas MV, Peláez C and Requena T, 2011. Effect of grape polyphenols on lactic acid bacteria and bifidobacteria growth: resistance and metabolism. Food microbiology, 28(7):1345-1352.

[56] Zago M, Fornasari ME, Carminati D, Burns P, Suàrez V, Vinderola G, Reinheimer J and Giraffa G, 2011. Characterization and probiotic potential of Lactobacillus plantarum strains isolated from cheeses. Food Microbiology, 28(5):1033-1040.

[57] Quatravaux S, Remize F, Bryckaert E, Colavizza D and Guzzo J, 2006. Examination of Lactobacillus plantarum lactate metabolism side effects in relation to the modulation of aeration parameters. Journal of applied microbiology, 101(4):903-912.

[58] Li P, Gu Q and Zhou Q, 2016. Complete genome sequence of Lactobacillus plantarum LZ206, a potential probiotic strain with antimicrobial activity against food-borne pathogenic microorganisms. Journal of biotechnology, 238:52-55.

[59] Zhu X, Zhao Y, Sun Y and Gu Q, 2014. Purification and characterisation of plantaricin ZJ008, a novel bacteriocin against Staphylococcus spp. from Lactobacillus plantarum ZJ008. Food chemistry, 165:216-23.

[60] Song DF, Zhu MY and Gu Q, 2014. Purification and characterization of plantaricin ZJ5, a new bacteriocin produced by Lactobacillus plantarum ZJ5. PLoS One, 9(8):e105549. 
Citation: Amro Abdelazez, Heba Abdelmotaal, Zong-Tao Zhu, Jia Fang-Fang, Rokayya Sami, Lu-ji Zhang, Abdel Rahman Al-Tawaha, Xiang-Chen Meng, 2018. Potential benefits of Lactobacillus plantarum as probiotic and its advantages in human health and industrial applications: A review. Advances in Environmental Biology., 12(1): 16-27.

[61] Nasrabadi MH, Aboutalebi H, Ebrahimi MT and Zahedi F, 2011. The healing effect of Lactobacillus plantarum isolated from Iranian traditional cheese on gastric ulcer in rats. African Journal of Pharmacy and Pharmacology, 5(12):1446-1451.

[62] Li C, Song J, Kwok LY, Wang J, Dong Y, Yu H, Hou Q, Zhang H and Chen Y, 2017. Influence of Lactobacillus plantarum on yogurt fermentation properties and subsequent changes during postfermentation storage. Journal of dairy science, 100(4):2512-2525.

[63] Salvucci E, LeBlanc JG and Pérez G, 2016. Technological properties of lactic acid bacteria isolated from raw cereal material. LWT-Food Science and Technology, 70:185-191.

[64] Tsafrakidou P, Bozoudi D, Pavlidou S, Kotzamanidis C, Hatzikamari M, Zdragas A and Litopoulou-Tzanetaki E, 2016. Technological, phenotypic and genotypic characterization of lactobacilli from Graviera Kritis PDO Greek cheese, manufactured at two traditional dairies. LWT-Food Science and Technology, 68:681-689.

[65] Hasslöf P, Hedberg M, Twetman S and Stecksén-Blicks C, 2010. Growth inhibition of oral mutans streptococci and candida by commercial probiotic lactobacilli-an in vitro study. BMC oral health, 10(1):18(1-6).

[66] González L, Sandoval H, Sacristán N, Castro JM, Fresno JM and Tornadijo ME, 2007. Identification of lactic acid bacteria isolated from Genestoso cheese throughout ripening and study of their antimicrobial activity. Food Control, 18(6):716-722.

[67] Cosentino S, Fadda ME, Deplano M, Melis R, Pomata R and Pisano MB, 2012. Antilisterial activity of nisin-like bacteriocin-producing Lactococcus lactis subsp. lactis isolated from traditional Sardinian dairy products. BioMed Research International, 376428: 1-8.

[68] Todorov SD, Rachman C, Fourrier A, Dicks LM, Van Reenen CA, Prévost H and Dousset X, 2011. Characterization of a bacteriocin produced by Lactobacillus sakei R1333 isolated from smoked salmon. Anaerobe, 17(1):23-31.

[69] Zacharof MP and Lovitt RW, 2012. Bacteriocins produced by lactic acid bacteria a review article. APCBEE Procedia, 2:50-56.

[70] Jiang $\mathrm{H}$, Li P and Gu Q, 2016. Heterologous expression and purification of plantaricin NC8, a two-peptide bacteriocin against salmonella spp. from lactobacillus plantarum ZJ316. Protein expression and purification, 127:28-34.

[71] Das D and Goyal A, 2013. Anti-listerial bactericidal activity of Lactobacillus plantarum DM5 isolated from fermented beverage Marcha. Probiotics and antimicrobial proteins, 5(3):206-215.

[72] Field D, O'Connor R, Cotter PD, Ross RP and Hill C, 2016. In vitro activities of nisin and nisin derivatives alone and in combination with antibiotics against Staphylococcus biofilms. Frontiers in microbiology, 7:508(1-11).

[73] Nissen-Meyer J, Rogne P, Oppegard C, Haugen HS and Kristiansen PE, 2009. Structure-function relationships of the non-lanthionine-containing peptide (class II) bacteriocins produced by gram-positive bacteria. Current pharmaceutical biotechnology, 10(1):19-37.

[74] Diep DB, Straume D, Kjos M, Torres C, Nes IF, 2009. An overview of the mosaic bacteriocin pln loci from Lactobacillus plantarum. Peptides, 30(8):15621574.

[75] Todorov SD, Prévost H, Lebois M, Dousset X, LeBlanc JG and Franco BD, 2011. Bacteriocinogenic Lactobacillus plantarum ST16Pa isolated from papaya (Carica papaya) - From isolation to application: Characterization of a bacteriocin. Food Research International, 44(5):1351-1363.

[76] Hauge HH, Mantzilas D, Eijsink VG and Nissen-Meyer J, 1999. Membrane-mimicking entities induce structuring of the two-peptide bacteriocins plantaricin E/F and plantaricin J/K. Journal of bacteriology, 181(3):740-747.

[77] Todorov SD, 2009. Bacteriocins from Lactobacillus plantarum production, genetic organization and mode of action: produção, organização genética e modo de ação. Brazilian Journal of Microbiology, 40(2):209-221.

[78] Prema P, Smila D, Palavesam A and Immanuel G, 2010. Production and characterization of an antifungal compound (3-phenyllactic acid) produced by Lactobacillus plantarum strain. Food and Bioprocess Technology, 3(3):379-386.

[79] Coloretti F, Carri S, Armaforte E, Chiavari C, Grazia L and Zambonelli C, 2007. Antifungal activity of lactobacilli isolated from salami. FEMS microbiology letters, 271(2):245-520.

[80] Dalié DK, Deschamps AM and Richard-Forget F, 2010. Lactic acid bacteria-Potential for control of mould growth and mycotoxins: A review. Food Control, 21(4):370-380.

[81] Gerez CL, Torino MI, Rollán G and De Valdez GF, 2009. Prevention of bread mould spoilage by using lactic acid bacteria with antifungal properties. Food Control, 20(2):144-148.

[82] Corsetti A, Gobbetti M, Rossi J and Damiani P, 1998. Antimould activity of sourdough lactic acid bacteria: identification of a mixture of organic acids produced by Lactobacillus sanfrancisco CB1. Applied Microbiology and Biotechnology, 50(2):253-256.

[83] Li H, Liu L, Zhang S, Cui W and Lv J, 2012. Identification of antifungal compounds produced by Lactobacillus casei AST18. Current microbiology, 65(2):156-161.

[84] Crowley S, Mahony J and van Sinderen D, 2013. Current perspectives on antifungal lactic acid bacteria as natural bio-preservatives. Trends in Food Science \& Technology, 33(2):93-109.

[85] Rejiniemon TS, Hussain RR and Rajamani B, 2015. In-vitro functional properties of Lactobacillus plantarum isolated from fermented ragi malt. South Indian Journal of Biological Sciences, (1):15-23.

[86] Crowley S, Mahony J and Sinderen D, 2012. Comparative analysis of two antifungal Lactobacillus plantarum isolates and their application as bioprotectants in refrigerated foods. Journal of applied microbiology, 113(6):1417-1427.

[87] Guillemard E, Tondu F, Lacoin F and Schrezenmeir J, 2010. Consumption of a fermented dairy product containing the probiotic Lactobacillus casei DN114001 reduces the duration of respiratory infections in the elderly in a randomised controlled trial. British journal of nutrition, 103(1):58-68.

[88] Thompson A, Van Moorlehem E and Aich P, 2010. Probiotic-induced priming of innate immunity to protect against rotaviral infection. Probiotics and antimicrobial proteins, 2(2):90-97.

[89] Youn HN, Lee DH, Lee YN, Park JK, Yuk SS, Yang SY, Lee HJ, Woo SH, Kim HM, Lee JB and Park SY, 2012. Intranasal administration of live Lactobacillus species facilitates protection against influenza virus infection in mice. Antiviral Research, 93(1):138-143.

[90] Annuk H, Shchepetova J, Kullisaar T, Songisepp E, Zilmer M and Mikelsaar M, 2003. Characterization of intestinal lactobacilli as putative probiotic candidates. Journal of Applied Microbiology, 94(3):403-412.

[91] Maeda N, Nakamura R, Hirose Y, Murosaki S, Yamamoto Y, Kase T and Yoshikai Y, 2009. Oral administration of heat-killed Lactobacillus plantarum L137 enhances protection against influenza virus infection by stimulation of type I interferon production in mice. International immunopharmacology, 9(9):1122-1125.

[92] Sunanliganon C, Thong-Ngam D, Tumwasorn S and Klaikeaw N, 2012. Lactobacillus plantarum B7 inhibits Helicobacter pylori growth and attenuates gastric inflammation. World journal of gastroenterology: WJG, 18(20): 2472-2480.

[93]. Korakli M, Rossmann A, Gänzle MG and Vogel RF, 2001. Sucrose metabolism and exopolysaccharide production in wheat and rye sourdoughs by Lactobacillus sanfranciscensis. Journal of Agricultural and Food Chemistry, 49(11):5194-5200.

[94] Harutoshi T, 2013. Exopolysaccharides of lactic acid bacteria for food and colon health applications. InLactic Acid Bacteria-R \& D for Food, Health and Livestock Purposes. InTech. 
Citation: Amro Abdelazez, Heba Abdelmotaal, Zong-Tao Zhu, Jia Fang-Fang, Rokayya Sami, Lu-ji Zhang, Abdel Rahman Al-Tawaha, Xiang-Chen Meng, 2018. Potential benefits of Lactobacillus plantarum as probiotic and its advantages in human health and industrial applications: A review. Advances in Environmental Biology., 12(1): 16-27.

[95] Ismail B and Nampoothiri KM, 2010. Production, purification and structural characterization of an exopolysaccharide produced by a probiotic Lactobacillus plantarum MTCC 9510. Archives of microbiology,192(12):1049-1057.

[96] Liu C, Lu J, Lu L, Liu Y, Wang F and Xiao M, 2010. Isolation, structural characterization and immunological activity of an exopolysaccharide produced by Bacillus licheniformis 8-37-0-1. Bioresource technology, 101(14):5528-5533.

[97] Dilna SV, Surya H, Aswathy RG, Varsha KK, Sakthikumar DN, Pandey A and Nampoothiri KM, 2015. Characterization of an exopolysaccharide with potential health-benefit properties from a probiotic Lactobacillus plantarum RJF4. LWT-Food Science and Technology, 64(2):1179-1186.

[98] Zhang Z, Liu Z, Tao X and Wei H, 2016. Characterization and sulfated modification of an exopolysaccharide from Lactobacillus plantarum ZDY2013 and its biological activities. Carbohydrate polymers, 153:25-33.

[99] Wang K, Li W, Rui X, Chen X, Jiang M and Dong M, 2014. Characterization of a novel exopolysaccharide with antitumor activity from Lactobacillus plantarum 70810. International journal of biological macromolecules, 63:133-139.

[100] Das D, Baruah R and Goyal A, 2014. A food additive with prebiotic properties of an $\alpha$-d-glucan from Lactobacillus plantarum DM5. International journal of biological macromolecules, 69:20-26.

[101] Das D and Goyal A, 2015. Antioxidant activity and $\gamma$-aminobutyric acid (GABA) producing ability of probiotic Lactobacillus plantarum DM5 isolated from Marcha of Sikkim. LWT-Food Science and Technology, 61(1):263-268.

[102] Blaschitz C and Raffatellu M, 2010. Th17 cytokines and the gut mucosal barrier. Journal of clinical immunology, 30(2):196-203.

[103] Galdeano CM, Núñez IN, de LeBlanc AD, Carmuega E, Weill R and Perdigón G, 2011. Impact of a probiotic fermented milk in the gut ecosystem and in the systemic immunity using a non-severe protein-energy-malnutrition model in mice. BMC gastroenterology, 11(1):64(1-14).

[104] Bloksma N, De Heer E, Van Dijk H and Willers JM, 1979. Adjuvanticity of lactobacilli. I. Differential effects of viable and killed bacteria. Clinical and experimental immunology, 37(2): 367-375.

[105] Bron PA, Van Baarlen P and Kleerebezem M, 2012. Emerging molecular insights into the interaction between probiotics and the host intestinal mucosa. Nature Reviews Microbiology, 10(1):66-78.

[106] Fredriksen L, Kleiveland CR, Hult LT, Lea T, Nygaard CS, Eijsink VG and Mathiesen G, 2012. Surface display of N-terminally anchored invasin by

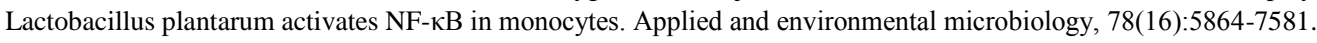

[107] Del Rio B, Seegers JF and Gomes-Solecki M, 2010. Immune response to Lactobacillus plantarum expressing Borrelia burgdorferi OspA is modulated by the lipid modification of the antigen. PLoS One, 5(6):e11199(1-10).

[108] Daniel C, Roussel Y, Kleerebezem M and Pot B, 2011. Recombinant lactic acid bacteria as mucosal biotherapeutic agents. Trends in biotechnology, 29(10):499-508.

[109] Rigaux P, Daniel C, Hisbergues M, Muraille E, Hols P, Pot B, Pestel J and Jacquet A, 2009. Immunomodulatory properties of Lactobacillus plantarum and its use as a recombinant vaccine against mite allergy. Allergy, 64(3):406-14.

[110] Gill N, Wlodarska M and Finlay BB, 2010. The future of mucosal immunology: studying an integrated system-wide organ. Nature immunology, 11(7):558560.

[111] Wittig B and Zeitz M, 2003. The gut as an organ of immunology. International journal of colorectal disease,18(3):181-187.

[112] Zhai Q, Xiao Y, Tian F, Wang G, Zhao J, Liu X, Chen YQ, Zhang H and Chen W, 2015. Protective effects of lactic acid bacteria-fermented soymilk against chronic cadmium toxicity in mice. RSC Advances, 5(6):4648-4658.

[113] Yu L, Zhai Q, Liu X, Wang G, Zhang Q, Zhao J, Narbad A, Zhang H, Tian F and Chen W 2016. Lactobacillus plantarum CCFM639 alleviates aluminium toxicity. Applied microbiology and biotechnology, 100(4):1891-900.

[114] Yu L, Zhai Q, Tian F, Liu X, Wang G, Zhao J, Zhang H, Narbad A and Chen W, 2016. Potential of Lactobacillus plantarum CCFM639 in protecting against aluminum toxicity mediated by intestinal barrier function and oxidative stress. Nutrients, 8(12):783(1-14).

[115] Kongnum $\mathrm{K}$ and Hongpattarakere T, 2012. Effect of Lactobacillus plantarum isolated from digestive tract of wild shrimp on growth and survival of white shrimp (Litopenaeus vannamei) challenged with Vibrio harveyi. Fish \& shellfish immunology, 32(1):170-177.

[116] Maeda M, Shibata A, Biswas G, Korenaga H, Kono T, Itami T and Sakai M, 2014. Isolation of lactic acid bacteria from kuruma shrimp (Marsupenaeus japonicus) intestine and assessment of immunomodulatory role of a selected strain as probiotic. Marine biotechnology, 16(2):181-192.

[117] Sornplang P and Piyadeatsoontorn S, 2016. Probiotic isolates from unconventional sources: a review. Journal of animal science and technology, 58(1):26(1$11)$.

[118] Kassayova M, Bobrov N, Strojný L, Kiskova T, Mikeš J, Demečková V, Orendáš P, Bojkova B, Péč M, Kubatka P and Bomba A, 2014. Preventive effects of probiotic bacteria Lactobacillus plantarum and dietary fiber in chemically-induced mammary carcinogenesis. Anticancer research, 34(9):4969-4975.

[119] Nguyen TD, Kang JH and Lee MS, 2007. Characterization of Lactobacillus plantarum pH04, a potential probiotic bacterium with cholesterol-lowering effects. International journal of food microbiology, 113(3):358-3561.

[120] Ducrotté P, Sawant P and Jayanthi V, 2012. Clinical trial: Lactobacillus plantarum 299v (DSM 9843) improves symptoms of irritable bowel syndrome. World journal of gastroenterology: WJG, 18(30):4012-4018.

[121] O’Brien E, Dolinoy DC and Mancuso P, 2014. Perinatal bisphenol A exposures increase production of pro-inflammatory mediators in bone marrow-derived mast cells of adult mice. Journal of immunotoxicology, 11(3):205-212.

[122] Song M, Yun B, Moon JH, Park DJ, Lim K and Oh S, 2015. Characterization of selected Lactobacillus strains for use as probiotics. Korean journal for food science of animal resources, 35(4):551-556.

[123] Song S, Oh S and Lim KT, 2016a. The glycoprotein (18 kDa) isolated from Lactobacillus plantarum L67 suppressed ß-hexosaminidase, histamine, and the expression of TNF- $\alpha$ and IL-4 in the BPA-stimulated RBL-2H3 cells. Process Biochemistry, 51(1):105-112.

[124] Song S, Oh S and Lim KT, 2016. Lactobacillus plantarum L67 glycoprotein protects against cadmium chloride toxicity in RAW 264.7 cells. Journal of dairy science, 99(3):1812-1821.

[125] Shori AB, 2016. Influence of food matrix on the viability of probiotic bacteria: A review based on dairy and non-dairy beverages. Food Bioscience, 13:1-8.

[126] Bezerra TK, de Oliveira Arcanjo NM, de Araújo AR, de Queiroz AL, de Oliveira ME, Gomes AM and Madruga MS, 2017. Volatile profile in goat coalho cheese supplemented with probiotic lactic acid bacteria. LWT-Food Science and Technology, 76:209-215.

[127] Cruxen CD, Hoffmann JF, Zandoná GP, Fiorentini ÂM, Rombaldi CV and Chaves FC, 2017. Probiotic butiá (Butia odorata) ice cream: development, characterization, stability of bioactive compounds, and viability of Bifidobacterium lactis during storage. LWT-Food Science and Technology, 75:379-385.

[128] Pot B and Tsakalidou E, 2009. Taxonomy and metabolism of Lactobacillus. Lactobacillus molecular biology: From genomics to probiotics, 1:1-56.

[129] Yue M, Cao H, Zhang J, Li S, Meng Y, Chen W, Huang L and Du Y, 2013. Improvement of mannitol production by Lactobacillus brevis mutant 3-A5 based on dual-stage $\mathrm{pH}$ control and fed-batch fermentations. World Journal of Microbiology and Biotechnology, 29(10):1923-1930.

[130] Settachaimongkon S, van Valenberg HJ, Gazi I, Nout MR, van Hooijdonk TC, Zwietering MH and Smid EJ, 2016. Influence of Lactobacillus plantarum WCFS1 on post-acidification, metabolite formation and survival of starter bacteria in set-yoghurt. Food microbiology, 59:14-22.

[131] Parvez S, Malik KA, Ah Kang S and Kim HY, 2006. Probiotics and their fermented food products are beneficial for health. Journal of applied microbiology, 100(6):1171-1185. 
Citation: Amro Abdelazez, Heba Abdelmotaal, Zong-Tao Zhu, Jia Fang-Fang, Rokayya Sami, Lu-ji Zhang, Abdel Rahman Al-Tawaha, Xiang-Chen Meng, 2018. Potential benefits of Lactobacillus plantarum as probiotic and its advantages in human health and industrial applications: A review. Advances in Environmental Biology., 12(1): 16-27.

[132] Johansson ML, Nobaek S, Berggren A, Nyman M, Björck I, Ahrne S, Jeppsson B and Molin G, 1998. Survival of Lactobacillus plantarum DSM 9843 $(299 \mathrm{v})$, and effect on the short-chain fatty acid content of faeces after ingestion of a rose-hip drink with fermented oats. International journal of food microbiology, (1-2):29-38.

[133] Johansson ML, Molin G, Jeppsson B, Nobaek S, Ahrne S and Bengmark S, 1993. Administration of different Lactobacillus strains in fermented oatmeal soup: in vivo colonization of human intestinal mucosa and effect on the indigenous flora. Applied and Environmental Microbiology, 59(1):15-20.

[134] McNaught CE, Woodcock NP, MacFie J and Mitchell CJ, 2002. A prospective randomised study of the probiotic Lactobacillus plantarum $299 \mathrm{~V}$ on indices of gut barrier function in elective surgical patients. Gut, 51(6):827-31.

[135] Kingamkono R, Sjögren E and Svanberg U, 1999. Enteropathogenic bacteria in faecal swabs of young children fed on lactic acid-fermented cereal gruels. Epidemiology \& Infection, 122(1):23-32.

[136] Cunningham-Rundles S, Ahrné S, Bengmark S, Johann-Liang R, Marshall F, Metakis L, Califano C, Dunn AM, Grassey C, Hinds G and Cervia J, 2000. Probiotics and immune response. The American journal of gastroenterology, 95(1):S22-S25.

[137] Wullt M, Hagslätt ML and Odenholt I, 2003. Lactobacillus plantarum 299v for the treatment of recurrent Clostridium difficile-associated diarrhoea: a double-blind, placebo-controlled trial. Scandinavian journal of infectious diseases, 35(6-7):365-367.

[138] Niedzielin K, Kordecki H and Birkenfeld B, 2001. A controlled, double-blind, randomized study on the efficacy of Lactobacillus plantarum 299V in patients with irritable bowel syndrome. European journal of gastroenterology \& hepatology, 13(10):1143-1147.

[139] Sen S, Mullan MM, Parker TJ, Woolner JT, Tarry SA and Hunter JO, 2002. Effect of Lactobacillus plantarum 299v on colonic fermentation and symptoms of irritable bowel syndrome. Digestive diseases and sciences, 47(11):2615-2620.

[140] Alander M, De Smet I, Nollet L, Verstraete W, Von Wright A and Mattila-Sandholm T, 1999. The effect of probiotic strains on the microbiota of the Simulator of the Human Intestinal Microbial Ecosystem (SHIME). International journal of food microbiology, ;46(1):71-79.

[141] McCracken VJ, Chun T, Baldeon ME, Ahrne S, Molin G, Mackie RI and Gaskins HR, 2002. TNF- $\alpha$ Sensitizes HT-29 Colonic Epithelial Cells to Intestinal Lactobacilli1. Experimental biology and medicine, 227(8):665-670.

[142] Michail S and Abernathy F, 2003. Lactobacillus plantarum inhibits the intestinal epithelial migration of neutrophils induced by enteropathogenic Escherichia coli. Journal of pediatric gastroenterology and nutrition, 36(3):385-391.

[143] Mack DR, Michail S, Wei S, McDougall L and Hollingsworth MA, 1999. Probiotics inhibit enteropathogenic E. coli adherence in vitro by inducing intestinal mucin gene expression. American Journal of Physiology-Gastrointestinal and Liver Physiology, 276(4):G941-G950.

[144] Perdigon G, Vintini E, Alvarez S, Medina M and Medici M, 1999. Study of the possible mechanisms involved in the mucosal immune system activation by lactic acid bacteria. Journal of dairy science, (6):1108-1114.

[145] Mangell P, Nejdfors P, Wang M, Ahrné S, Weström B, Thorlacius H and Jeppsson B, 2002. Lactobacillus plantarum 299v inhibits Escherichia coli-induced intestinal permeability. Digestive diseases and sciences, 47(3):511-516.

[146] Liu Q, Nobaek S, Adawi D, Mao Y, Wang M, Molin G, Ekelund M and Jeppsson B, 2001. Administration of Lactobacillus plantarum 299v reduces side-effects of external radiation on colon anastomotic healing in an experimental model. Colorectal Disease, 3(4):245-252.

[147] Toshimitsu T, Mochizuki J, Ikegami S and Itou H, 2016. Identification of a Lactobacillus plantarum strain that ameliorates chronic inflammation and metabolic disorders in obese and type 2 diabetic mice. Journal of dairy science, 99(2):933-946.

[148] Park SY, Cho SA, Kim SH and Lim SD, 2014. Physiological characteristics and anti-obesity effect of lactobacillus plantarum Q180 isolated from feces. Korean journal for food science of animal resources, 34(5):647-655

[149] Lee SJ, Bose S, Seo JG, Chung WS, Lim CY and Kim H, 2014. The effects of co-administration of probiotics with herbal medicine on obesity, metabolic endotoxemia and dysbiosis: A randomized double-blind controlled clinical trial. Clinical Nutrition, 33(6):973-981.

[150] Li C, Nie SP, Zhu KX, Xiong T and Xie MY, 2016. Lactobacillus plantarum NCU116 fermented carrot juice evokes changes of metabolites in serum from type 2 diabetic rats. Food Research International, 80:36-40.

[151] Kim ST, Kim HB, Lee KH, Choi YR, Kim HJ, Shin IS, Gyoung YS and Joo SS, 2012. Steam-dried ginseng berry fermented with Lactobacillus plantarum controls the increase of blood glucose and body weight in type 2 obese diabetic db/db mice. Journal of agricultural and food chemistry, 60(21):5438-5445.

[152] Nguyen TD, Kang JH and Lee MS, 2007. Characterization of Lactobacillus plantarum PH04, a potential probiotic bacterium with cholesterol-lowering effects. International journal of food microbiology, 113(3):358-361.

[153] Kumar R, Grover S and Batish VK, 2011. Hypocholesterolaemic effect of dietary inclusion of two putative probiotic bile salt hydrolase-producing Lactobacillus plantarum strains in Sprague-Dawley rats. British Journal of Nutrition, 105(4):561-573.

[154] Mohania D, Kansal VK, Shah D, Nagpal R, Kumar M, Gautam SK, Singh B and Behare PV, 2013. Therapeutic effect of probiotic dahi on plasma, aortic, and hepatic lipid profile of hypercholesterolemic rats. Journal of Cardiovascular pharmacology and Therapeutics, 18(5):490-497.

[155] Tomaro-Duchesneau C, Jones ML, Shah D, Jain P, Saha S and Prakash S, 2014. Cholesterol assimilation by Lactobacillus probiotic bacteria: an in vitro investigation. BioMed research international, 380316,1-9.

[156] Bukowska H, Pieczul-Mroz J, Jastrzebska M, Chelstowski K and Naruszewicz M, 1998. Decrease in fibrinogen and LDL-cholesterol levels upon supplementation of diet with Lactobacillus plantarum in subjects with moderately elevated cholesterol. Atherosclerosis, 137(2):437-438.

[157] Naruszewicz M, Johansson ML, Zapolska-Downar D and Bukowska H 2002. Effect of Lactobacillus plantarum 299v on cardiovascular disease risk factors in smokers. The American journal of clinical nutrition, 76(6):1249-1255.

[158] Hong SM, Chung EC and Kim CH, 2015. Anti-obesity effect of fermented whey beverage using lactic acid bacteria in diet-induced obese rats. Korean journal for food science of animal resources, 35(5):653 -659.

[159] Lee KH, Song JL, Park ES, Ju J, Kim HY and Park KY, 2015. Anti-obesity effects of starter fermented Kimchi on 3T3-L1 adipocytes. Preventive nutrition and food science, 20(4):298-302.

[160] Lee BH, Lo YH and Pan TM, 2013. Anti-obesity activity of Lactobacillus fermented soy milk products. Journal of Functional Foods, 5(2):905-913. 